\title{
Hubungan Emosi Positif dan Koping dengan Hipertensi di RSUP. M. Djamil Padang
}

\author{
Fitra Yeni ${ }^{\mathrm{a}}$ \\ aProgram Studi Ilmu Keperawatan Universitas Andalas
}

\begin{abstract}
The number of visitation of patient who suffered hypertension in Dr. M. Djamil Hospital is increased by 914 in 2006 and 1892 in 2007. The aim of this study is to know the correlation between emotional and coping tend blood pressure. This correlation study was conducted in to 86 sample that have the ability to read and write in Padang city and also include in the age of less than 60 years old. The analysis which is used in this study was double correlation parameter analysis. The result of this data analysis was there are significant correlations between positive emotion and proactive coping as a variable control with systolic blood pressure and diastolic blood pressure, which was produced significant coeficient test with the value $p=0,002$ and $p=0,025$
\end{abstract}

Keywords: positive emotion, proactive coping and blood pressure

\begin{abstract}
Abstrak: Jumlah kunjungan pasien mengalami hipertensi dirumah sakit Dr.M.Djamil padang terus meningkat, tahun 2006 sekitar 914 dan Meningkat 1892 pada ahun 2007, penelitian ini bertujuan untuk mengetahui hubungan antara emosi positif dan koping proaktif terhadap tekanan darah. penelitian korelasi ini dilakukan pada 86 orang dengan kriteria sampel bisa membaca dan menulis berdomisili di kota padang, usia dibawah 60 tahun, analisis yang digunakan dalam penelitian ini adalah teknik analisis korelasi berganda parametrik. Hasil analisis data didapatkan terdapat hubungan bermakna antara emosi positif dan koping proaktif sebagai variable control dengan tekanan darah sistolik dan diastolik dimana diperoleh uji signifikansi koefisien sebesar $p=0,002$ dan $p=0,025$
\end{abstract}

Kata kunci: emosi positif, koping proaktif dan tekanan darang

Pada akhir abad 20, penyakit jantung dan pembuluh darah menjadi penyebab utama kematian di negara maju dan negara berkembang. Dan saat ini hipertensi terdaftar sebagai penyakit pembunuh ketiga setelah penyakit jantung dan kanker. Di dunia, hampir 1 milyar orang atau 1 dari 4 orang dewasa menderita tekanan darah tinggi. Jumlah ini diperkirakan meningkat menjadi 1,6 miliar menjelang 2025. Hipertensi menyerang paling tidak $29 \%$ orang dewasa di Amerika Serikat. Setiap tahun darah tinggi menjadi penyebab 1 dari setiap 7 kematian (7 juta per tahun) disamping menyebabkan kerusakan jantung, mata, otak dan ginjal (www.kompas.com, dikutip dari WHO, 1999)

Penyakit hipertensi merupakan peningkatan tekanan darah yang memberi gejala yang berlanjut untuk suatu target organ, seperti strok untuk otak, penyakit jantung koroner untuk pembuluh darah jantung dan untuk otot jantung. Penyakit ini telah menjadi masalah utama dalam kesehatan mesyarakat yang ada di Indonesia maupun di beberapa negara yang ada di dunia (Ridwanamiruddin, 2007). Di bagian lain di Asia, tercatat 38,4 juta penderita Hipertensi pada 2000 dan diprediksi jadi 67,4 juta orang pada 2025. Di Indonesia, mencapai $17-21 \%$ dari 
populasi penduduk dan kebanyakan tidak terdeteksi (www.kompas.com, dikutip dari WHO, 1999).

Hipertensi tidak dapat disembuhkan tetapi dapat dikendalikan. Ada dua cara untuk menurunkan Hipertensi, yaitu pengobatan dan perubahan pola hidup sehat dengan mengendalikan faktor resiko (Selamiharjo, 2005 dikutip dari Shep, 2002). Dari pengalaman klinis diketahui, penggunaan obat secara teratur untuk mengendalikan tekanan darah dapat menurunkan angka kematian akibat penyakit jantung dan stroke. Meski obat tersebut amat penting perannya dalam pengobatan, para pakar Hipertensi berpendapat, pola hidup sehat dengan mengendalikan faktor resiko tetap merupakan dasar pencegahan dan pengobatan hipertensi, faktor resiko yang dapat di kendalikan antara lain obesitas, kurang aktifitas fisik, konsumsi makanan yang berlebih, merokok, alkohol dan kopi.

Banyak literatur menyebutkan hal yang sama mengenai faktor resiko yang dapat dikendalikan, sementara pembahasan tentang peranan emosi dan koping dalam kaitannya sebagai faktor resiko Hipertensi sangat terbatas, walaupun bukti-bukti yang menunjukkan bahwa emosi positif bisa melindungi kesehatan semakin meningkat. Beberapa studi telah menemukan hubungan antara pengaruh positif dan perubahan psikologis terkait dengan fungsi imun yang lebih baik. (Futterman, Kemeny, Shapiro, \& Fahey, 1994). Fungsi kekebalan yang meningkat juga dihubungkan dengan dengan menurunnya kemungkinan untuk terkena penyakit infeksi. Cohen, Doyle, Tumer, Alper \& Skoner (2003) menemukan bahwa kecenderungan menggunakan emosi positif dihubungkan dengan ketahanan yang lebih besar terhadap perkembangan demam biasa. Subskala kuisioner mengukur tipe emosi positif, terdiri dari aitem-aitem yang mengukur perasaan semangat, ketenangan dan kesejahteraan, dan dihubungkan dengan praktek kesehatan yang lebih baik, juga tingkat basal yang lebih rendah pada epinephrine, norepinephrine, dan kortisol. Penelitian lain telah menemukan hubungan yang kuat antara pengalaman emosi positif dan panjang umur. Dalam sebuah analisis dari autobiografi menemukan bahwa para biarawati yang tulisannya kurang memiliki emosi positif yang berusia 22 tahun, memiliki resiko 2.5 kali lebih besar untuk meninggal lebih cepat daripada yang menulis dengan isi emosi positif (Compton, 2005).

Emosi negatif sering dihubungkan dengan peningkatan tekanan darah. Sebuah penelitian menunjukkan bahwa intensitas marah yang tinggi dan menekan ekspresi marah tersebut meningkatkan resiko untuk Hipertensi (Markovitz, 1993). Penelitian lain menunjukkan bahwa emosi positif ternyata mempunyai pengaruh melebihi emosi negatif terhadap Hipertensi. Orang yang mempunyai emosi positif yang tinggi walaupun memiliki emosi negatif, resiko mengalami hipertensi berikutnya lebih rendah dibanding orang yang memiliki emosi positif yang rendah. Bukti epidemiologis terbaru menunjukkan bahwa emosi negatif dapat berperan penting dalam perkembangan berbagai penyakit, seperti diabetes (Carnethon, Kinder, Fair, Stafford, \& Fortmann, 2003) dan hipertensi (Everson, Goldberg, Kaplan, Julkunen, \& Salonen, 1998; Jonas, Franks, \& Ingram). Sebagai contoh, Jonas et. al (1997) menemukan bahwa kecemasan tingkat tinggi dihubungkan dengan risiko 2 sampai 3 kali lebih besar menderita hipertensi pada orang kulit putih dan hitam.

Penilaian terhadap stres sangat dipengaruhi oleh koping sehingga efek stres juga akan berbeda tergantung bagaimana menilainya. Koping merupakan respon terhadap stres atau bagaimana seseorang berupaya mengatasi masalah atau mengatasi emosi yang umumnya negatif. Koping merupakan cara untuk merubah emosi negatif menjadi emosi positif. Berbagai kondisi yang dinilai 
sebagai suatu kondisi yang penuh stres, terbukti meningkatkan tekanan darah yang berlangsung dalam jangka waktu pendek. Beberapa penelitian yang dilakukan terhadap hewan percobaan menunjukkan stres dapat menaikkan tekanan darah sistol maupun diastol. Percobaan yang dilakukan terhadap beberapa mahasiswa dengan memberikan tugas-tugas yang menimbulkan kondisi stres menunjukkan kenaikan tekanan darah sistole dan diastole yang beragam. Kondisi ini dipengaruhi oleh koping yang digunakan oleh masingmasing mahasiswa juga berbeda. (Davison, Neale, Kring, 2004).

Berdasarkan data dari rekam medis unit rawat jalan Rumah Sakit Dr M. Djamil Padang, pada tahun 2006 penderita Hipertensi di poliklinik penyakit jantung berjumlah 914 orang. Sedangkan pada tahun 2007 penderita Hipertensi di poliklinik penyakit jantung meningkat menjadi 1892 orang . Poli Khusus Hipertensi ini dibuka setiap hari Senin dan Kamis dengan kunjungan rata-rata 150 orang. Sebagai rumah sakit rujukan, maka pasien yang datang juga berasal dari berbagai daerah di sekitar Kota Padang. Kegiatan yang dilakukan di Poli Khusus Hipertensi terkait dengan Hipertensi sendiri belum ada. Hal ini membuat kebutuhan pasien akan informasi tentang Hipertensi menjadi sangat terbatas.

Berdasarkan hal diatas, maka perlu diadakan penelitian tentang hubungan emosi positif dan koping dengan hipertensi, mengingat kasusnya yang terus meningkat sementara beberapa faktor pencetusnya dapat dikendalikan, termasuk emosi dan koping. Diharapkan hasil penelitian ini dapat menjadi bahan pertimbangan untuk terapi hipertensi nonfarmakologi.

\section{METODE}

\section{Emosi Positif}

Banyak penelitian tentang pemikiran yang positif dan kesehatan memiliki perbedaan yang bercampur antara emosi positif dan faktor psikologis positif yang lain seperti optimisme. Kenyataaannya, hanya ada sedikit kesepakatan tentang apa yang dipertimbangkan sebagai emosi positif. Teori emosi terkemuka secara umum gagal untuk menjelaskan emosi positif yang cenderung untuk berkembang daripada emosi negatif. Barbara (2001), mengembangkan model emosi positif broden-and-buid yang mengidentifikasi empat kelompok emosi positif kegembiraan, ketertarikan, kepuasan hati dan cinta - dan beralasan bahwa dalam kelompok emosi tersebut, keadaan afektif yang beragam bisa dicirikan dengan sebuah tema umum dan juga variasi dari tema tersebut. Meskipun tidak setiap pemikiran positif dipertimbangkan sebagai emosi positif, pada awal pemahaman, definisi yang luas tentang emosi kemungkinan dapat membantu menjelaskan. Dua kemampuan emosi yang terkait kesehatan yang telah muncul pada literatur adalah harapan dan keingintahuan dan pada dasar definisi konseptual keduanya bisa dimasukkan dalam kelompok ketertarikan (emosi interes). Emosi dalam kelompok ini dihubungkan dengan kepekaan terhadap tantangan dan motivasi intrinsik, peka terhadap kemungkinan dan kecenderungan terhadap eksplorasi (Compton, 2005).

Banyak pengukuran yang digunakan dalam mengukur emosi positif. Dalam penelitian ini, emosi positif diukur dengan menggunakan Intensity and Time Affect Survery (ITAS) yang dikembangkan oleh Lucas dkk. Beberapa emosi merupakan gabungan dari emosi positif yang telah ada.

Model emosi dan kesehatan telah dikembangkan untuk memahami hubungannya dan mekanisme tentang hubungan emosi negatif dengan penurunan kesehatan. Model ini mengidentifikasi dua jalan, jalan langsung yang melibatkan aktivasi psikologis dan jalan tidak langsung yang melibatkan perilaku, kognisi dan sumber koping. Berbagai macam pengaruh psikologis telah 
diajukan, meliputi perubahan pada stabilitas elektrik pada jantung, aktivasi sistem syaraf simpatik kronis, pelepasan katekolamin, disregulasi aksis kelenjar adrenal-hipotalamus, disregulasi serotonergic dan disfungsi endothelial. Perilaku-perilaku yang didukung oleh emosi negatif dapat mengakibatkan pengaruh yang jangka pendek dan jangka panjang terhadap psikologi dan kesehatan (Compton, 2005).

\section{Koping Proaktif}

Menurut Shane (2003), perspektif terbaru dari koping dibedakan atas dapat cepat bereaksi (reaktif), dapat cepat mengantisipasi (anticipatory), penuh dengan rasa waspada (preventif) dan koping proaktif. Setiap tipe dari koping ini menolong kita bergulat menghadapi kejadian-kejadian di masa lalu, saat ini dan masa depan.

Koping Reaktif menyangkut kepada saat mengalami rasa ancaman bahaya atau pengalaman kehilangan di masa lalu. Sedangkan Koping Anticipatory menyangkut ancaman terdekat di masa depan yang menjelang. Koping Preventif memberi tanda kepada hal sesuatu yang tidak pasti namun berpotensi mengancam di masa depan yang jauh. Koping Proaktif menyangkut kepada tantangan atau ancaman yang berpotensi meningkatkan kemampuan dan kekuatan dalam diri sendiri untuk menghadapi tantangan atau ancaman tersbut.

Suatu contoh dari Koping positif adalah Koping proaktif karena Koping proaktif tidak membutuhkan penilaian negatif lainnya, seperti misalnya mengalami kerugian/kerusakan, kehilangan, atau ancaman. Koping proaktif menggambarkan suatu usaha untuk membangun dan mengembangkan sumbersumber yang memfasilitasi kemajuan melalui penetapan tujuan-tujuan dan pertumbuhan personal. Di dalam Koping proaktif, orang-orang bertahan dalam impian mereka. Mereka melihat sumber bahaya, tuntutan-tuntutan (permintaan- permintaan), kesempatan-kesempatan mendapat acaman di masa depan yang mendatang, tetapi mereka tidak melihat hal-hal ini sebagai hal yang potensial mengancam di masa depan. Lebih kepada hal itu, mereka menerima banyak situasi permintaan sebagai tantangan personal. Koping dapat menjadi alat untuk memanajemen tujuan daripada memanajemen risiko. Individu-individu tidak reaktif tetapi proaktif di dalam perasaaan yang mana mereka memulai sebuah bagian konstruksi dari pekerjaan dan menciptakan kesempatan untuk proses perkembangan. Individu yang proaktif berusaha untuk perbaikan kehidupan mereka dan membangun sumber-sumber yang memastikan kemajuan dan kualitas dari fungsi. Koping proaktif menciptakan kondisi kehidupan yang lebih baik dan tingkatan penampilan yang lebih tinggi yang dialami sebagai sebuah kesempatan untuk memberikan arti kehidupan secara penuh. Stress dipresentasikan sebagai "eustress" yang memproduksi energy vital dan menggetarkan (Selye, 1974).

Koping sudah dapat diukur atau dinilai sebagian besarnya menggunakan kuisioner-kuisioner, misalnya member tanda check list atau menggunakan skala psikometrik. Pada pembahasan sebelumnya Schwarzer dan Schwarezer (1996) menggambarkan 13 inventaris konvensional yang didesain untuk menilai aspek dari koping. Pengukuran ini meliputi pengukuran beberapa variasi dari subskala untuk menemukan keseluruhan area koping perilaku, misalnya proses pemecahan masalah, penghindaran terhadap masalah, proses pencaharian informasi social dan dukungan social, proses penyangkalam dan penolakan, proses pencarian pengharapan kembali dan lain-lain. Satu yang menjadi kesimpulan untuk menilai koping di dalam sebuah kelakuan yang memuaskan ternyata lebih sulit. Koping adalah suatu hal yang memiliki keistimewaan luar biasa sekali, dan lebih rumit dalam menentukan jika 
hanya menggunakan faktor situasional dan faktor personal.

Koping preventif bertujuan untuk kejadian peristiwa yang tidak pasti yang mungkin akan terbayang di masa depan yang jauh. Orang-orang mengumpulkan sumber-sumber dan mengambil langkah pencegahan umum agar dapat terlindungi dari berbagai macam ancaman/bahaya. Ada 10 item skala koping preventif yang termasuk ke dalam inventaris koping proaktif (PCI; Greenglass, 1999). Hal-hal yang khusus termasuk, "Saya akan merencanakan sesuatu di masa depan pada akhirnya," "sebelum penderitaan menyerang saya, saya harus mempersiapkan diri saya untuk konsekuensinya," dan "saya mempersiapkan diri saya untuk peristiwa yang tidak saya inginkan." PCI meliputi subskala koping proaktif yang telah diuji pada beberapa macam sampel dan tersedia dalam beberapa macam bahasa. Di PCI ada terdapat 14 item yang berbentuk skala unidimensional.

\section{Hipertensi}

Hipertensi atau tekanan darah tinggi adalah naiknya tekanan pada pembuluh darah arteri yang disebabkan oleh dua faktor utama yang dapat hadir secara independent dan bersamaan, yaitu: daya pompa jantung dengan kekuatan yang besar dan pembuluh darah dan pembuluh darah kecil (arteriol) menyempit sehingga aliran darah memerlukan tekanan yang besar untuk melawan dinding pembuluh darah tersebut (Silbernagl dan Lang, 2005).

Berdasarkan klasifikasi dari Joint National Committen On Hypertention VI (JNC VI) (1997, dalam Darmajo, 2004) hipertensi dapat dibedakan menjadi: Hipertensi sistolik (Isolated Systolik Hypertention), adalah hipertensi yang terjadi ketika tekanan sistolik lebih dari $140 \mathrm{mmHg}$, namun tekanan diastolik dalam batas normal; Hipertensi diastolik, yaitu hipertensi yang terjadi ketika tekanan darah diastolik lebih dari $90 \mathrm{mmHg}$.
Insidensi menurun dengan bertambahnya usia; Hipertansi sistolik-diastolik, yaitu hipertensi yang terjadi ketika terjadi peningkatan darah sistolik dan diastolik iasidensi meningkat dengan bertambahnya usia.

Tekanan sistolik yang tinggi (hipertensi sistolik) diketehui merupakan faktor resiko yang besar untuk terkena komplikasi penyakit jantung, ginjal, dan sirkulasi bahkan kematiaan. Semakin besar jarak antara tekanan darah sistolik dan diastolik, maka semakin besar bahayanya (Kannel et al, 2001). Seperti semua penyakit degeneratif, hipertensi biasanya tidak memberi gejala apapun atau gejala yang timbul samar-samar (insidensius) atau tersembunyi (occult), seringkali yang terlibat adalah gejala akibat penyakit, komplikasi atau penyakit yang menyertai (Darmajo, 2004).

\section{METODOLOGI PENELITIAN}

Penelitian ini merupakan penelitian korelasi dimana tujuan penelitian ini adalah untuk mengetahui kekuatan hubungan antara emosi dan tekanan darah dimana koping dijadikan sebagai varibel kontrol. Analisis yang digunakan dalam penelitian ini adalah teknik analisis korelasi berganda parametrik.

Sampel penelitian adalah pasien hipertensi yang datang ke Poliklinik Khusus Ginjal/Hipertensi di RS Dr. M. Djamil Padang. Metode sampling yang digunakan adalah purposive sampling, dengan kriteria sampel: bisa membaca dan menulis, berdomisili di kota padang, usia dibawah 60 tahun pada tahun 2010, berat badan dalam rentang normal dan datang berobat ke poli.

Emosi diukur dengan menggunakan skala emosi positif yang dikembangkan dari Intensity and Time Affect Survery (ITAS). Koping proaktif diukur dengan skala koping proaktif yang dikembangkan dari Proactive Coping Inventories (PCI). Analisis Data dilakukan dengan menggunakan bantuan komputer. 
HASIL PENELITIAN DAN

PEMBAHASAN

Hasil

Pengambilan data dilakukan mulai dari tanggal 20 September sampai tanggal 7 Oktober 2010 setiap hari kunjungan hipertensi yaitu hari Senin dan Kamis. Rata-rata kunjungan pasien setiap harinya sekitar 150 orang dan sebagian besar adalah pasien hipertensi esensial dengan usia dibawah 60 tahun. Pasien akan kembali ke poli khusus jantung/hipertensi tiga minggu kemudian untuk kelanjutan pengobatan. Metode sampling yang digunakan adalah purposive sampling, dengan kriteria sampel: bisa membaca dan menulis, berdomisili di kota padang, usia dibawah 60 tahun pada tahun 2010 dan bersedia menjadi responden. Responden berjumlah 86 orang.
Emosi

diukur dengan menggunakan skala emosi positif dengan 8 aitem pernyataan yang dikembangkan dari Intensity and Time Affect Survery (ITAS). Koping proaktif diukur dengan skala koping proaktif dengan 45 aitem pernyataan yang dikembangkan dari Proactive Coping Inventories (PCI). Analisis Data dilakukan dengan menggunakan bantuan program SPSS release 15.0 for Windows

Analisis deskriptif ditujukan untuk mengetahui kecenderungan respon subyek penelitian terhadap tiap-tiap variabel penelitian. Deskripsi data penelitian berupa skor empirik dan teoritik untuk variabel emosi positif dan koping proaktif disajikan pada tabel berikut.

Tabel 1. Deskripsi Data Emosi Positif dan Koping Proaktif

\begin{tabular}{|c|c|c|c|c|c|c|c|c|}
\hline \multirow{2}{*}{ Variabel } & \multicolumn{4}{|c|}{ Skor Empirik } & \multicolumn{4}{c|}{ Skor Teoritik } \\
\cline { 2 - 10 } & Min & Mak & Mean & SD & Min & Mak & Mean & SD \\
\hline Emosi positif & 33 & 56 & 45,95 & 6,517 & 8 & 56 & 32 & 8 \\
\hline Koping proaktif & 56 & 95 & 82,95 & 9,582 & 45 & 180 & 112,5 & 22,5 \\
\hline
\end{tabular}

Data pada Tabel 1 akan digunakan untuk mengetahui kecenderungan respon subyek penelitian terhadap tiap-tiap variabel penelitian, maka dibuat klasifikasi pada tiap-tiap variabel penelitian berdasarkan norma. Norma disusun berdasarkan tingkat diferensiasi yang dikehendaki, yang batasannya ditetapkan berdasarkan satuan deviasi standar dengan memperhitungkan rentang nilai minimummaksimum teoritiknya. Dalam penelitian ini skala emosi positif dan koping proaktif dibagi menjadi tiga kategori, sehingga keenam satuan deviasi standar dibagi menjadi tiga bagian (Azwar, 2003), yaitu:

$$
\begin{array}{rl}
<\mathrm{Mt}-1 . \mathrm{SDt} & =\text { Rendah } \\
\mathrm{Mt}-1 . \mathrm{SDt} \mathrm{s} / \mathrm{d} & \mathrm{Mt}+1 . \mathrm{SDt}=\text { Sedang } \\
> & \mathrm{Mt}+1 . \mathrm{SDt}=\text { Tinggi }
\end{array}
$$

Keterangan:
Mt adalah mean teoritik yang diperoleh dari rumus $1 / 2 \times$ (nilai maksimum teoritik + nilai minimum teoritik), dan SDt adalah standar deviasi teoritik yang diperoleh dari rumus $1 / 6 \mathrm{x}$ (nilai maksimum teoritik nilai minimum teoritik).

Skala emosi positif diukur dengan 8 aitem dalam skala 7 poin dengan rentang $1-7$, sehingga nilai maksimum teoritik yang mungkin dicapai adalah $=8 \times 7=56$ dan nilai minimum sebesar $8 \times 1=8$. Mean teoritik diperoleh sebesar $1 / 2 \times(56+$ $8)=32$ dan standar deviasi teoritik sebesar $1 / 6 \times(56-8)=8$. Berdasarkan harga $\mathrm{Mt}=$ 32 dan SDt $=8$ akan diperoleh kategorikategori skor emosi positif seperti yang disajikan pada tabel berikut. 
Tabel 2. Distribusi Frekuensi Emosi Positif

\begin{tabular}{|c|c|c|c|}
\hline Kategori & Rentang Nilai & Frekuensi & Persentase \\
\hline Rendah & $<24$ & 0 & $0 \%$ \\
\hline Sedang & $24-40$ & 22 & $25,6 \%$ \\
\hline Tinggi & $>40$ & 64 & $74,4 \%$ \\
\hline Total & & 86 & $100 \%$ \\
\hline
\end{tabular}

Berdasarkan Tabel 2 di atas dapat dilihat bahwa dari 86 responden, tidak terdapat responden yang termasuk kategori rendah $(0 \%), 22$ responden $(25,6 \%)$ termasuk kategori sedang dan 64 responden $(74,4 \%)$ termasuk kategori tinggi. Pada Tabel 1 (hal 17), mean empirik emosi positif ditemukan sebesar 45,95 . Nilai ini berada di atas rentang nilai 40, yang menunjukkan bahwa responden penelitian memiliki emosi positif yang tinggi.
Skala koping proaktif diukur dengan 45 aitem dalam skala 4 poin dengan rentang $1-4$, sehingga nilai maksimum teoritik yang mungkin dicapai adalah $=25 \times 4=100$ dan nilai minimum sebesar $25 \times 1=25$. Mean teoritik diperoleh sebesar $1 \frac{1}{2} \times(100+25)=62,5$ dan standar deviasi teoritik sebesar 1/6 x (100$25)=12,5$. Berdasarkan harga $\mathrm{Mt}=62,5$ dan SDt $=12,5$ akan diperoleh kategorikategori skor koping proaktif seperti yang disajikan pada tabel berikut.

Tabel 3. Distribusi Frekuensi Koping Proaktif

\begin{tabular}{|c|c|c|c|}
\hline Kategori & Rentang Nilai & Frekuensi & Persentase \\
\hline Rendah & $<50$ & 0 & $0 \%$ \\
\hline Sedang & $50-75$ & 18 & $20,9 \%$ \\
\hline Tinggi & $>75$ & 68 & $79,1 \%$ \\
\hline Total & & & \\
\hline
\end{tabular}

Berdasarkan Tabel 3 di atas dapat dilihat bahwa dari 86 responden, tidak ada responden yang termasuk kategori rendah $(0 \%), 18$ responden $(20,9 \%)$ termasuk kategori sedang, dan 68 responden $(79,1 \%)$ termasuk kategori tinggi. Pada Tabel 1 (hal 17), mean empirik koping proaktif ditemukan sebesar 82,26. Nilai ini berada di atas rentang nilai 75 yang menunjukkan bahwa responden penelitian memiliki koping proaktif yang tinggi.
Tekanan darah diukur dengan menggunakan Sphygmomanometer yang telah dikalibrasi dan validasinya terjamin. Pasien diukur dalam posisi duduk dan istirahat selama 5 menit dengan kaki diatas lantai dan lengan sejajar dengan letak jantung (Syaifuddin, 2006). Tekanan darah dikatakan normal apabila tekanan sistolik dibawah atau sama dengan $140 \mathrm{mmHg}$ dan tekanan diastolik dibawah atau sama dengan $90 \mathrm{mmHg}$. Data tekanan darah disajikan pada tabel berikut:

Tabel 4. Distribusi Frekuensi Tekanan Darah

\begin{tabular}{|c|c|c|c|}
\hline Variabel & Normal (f) & Tidak Normal(f) & Jumlah \\
\hline Tekanan Darah Sistolik & 36 & 50 & 86 \\
& $(41,9 \%)$ & $(58,1 \%)$ & $(100 \%)$ \\
\hline Tekanan Darah Diastolik & 56 & 30 & 86 \\
& $(65,1 \%)$ & $(34,9 \%)$ & $(100 \%)$ \\
\hline
\end{tabular}


Berdasarkan Tabel 4 di atas dapat dilihat bahwa dari 86 responden, terdapat 50 responden $(58,1 \%)$ dengan tekanan darah sistolik yang tidak normal dan 30 responden $(34,9 \%)$ dengan tekanan darah diastolik yang tidak normal.
Uji hipotesis dalam penelitian ini dilakukan dengan menggunakan komputer program SPSS for windows release 15.0. Estimasi model korelasi berganda mengenai emosi positif, koping proaktif dan tekanan darah diperoleh hasil sebagai berikut.

Tabel 5. Hasil Korelasi Berganda

\begin{tabular}{|c|c|l|c|c|c|}
\hline Variabel Kontrol & Variabel Bebas & Variabel Terikat & $\mathrm{r}$ & $\mathrm{r}$ & $\mathrm{Sig}$ \\
\hline Koping Proaktif & Emosi Positif & $\begin{array}{l}\text { Tekanan Darah } \\
\text { Sistolik }\end{array}$ & -.467 & 0,218 & .002 \\
\cline { 3 - 6 } & & $\begin{array}{l}\text { Tekanan Darah } \\
\text { Diastolik }\end{array}$ & -.346 & 0,121 & .025 \\
\hline
\end{tabular}

Berdasarkan Tabel 5 di atas dapat dilihat bahwa dari hasil analisis korelasi emosi positif dan koping proaktif sebagai variabel kontrol dengan tekanan darah sistolik, diperoleh uji signifikansi koefisien sebesar $\mathrm{p}=0,002(\mathrm{p}<0,05)$ yang berarti terdapat hubungan yang bermakna. Angka korelasi $(r)=-0,467$ yang berarti terdapat hubungan sedang yang negatif, yakni semakin tinggi emosi positif dan koping proaktif maka tekanan darah sistolik akan semakin rendah. Ditemukan pula koefisien determinasi (r ) sebesar 0,218 yang berarti bahwa sekitar $22 \%$ sumbangan emosi positif dan koping proaktif terhadap variabel tekanan darah sistolik, sedangkan sisanya sebesar $78 \%$ dijelaskan oleh prediktor lain dan kesalahan kesalahan lain (eror sampling dan non sampling).

Pada Tabel 5 juga dapat dilihat analisis korelasi emosi positif dan koping proaktif sebagai variabel kontrol dengan tekanan darah diastolik, diperoleh uji signifikansi koefisien sebesar $\mathrm{p}=0,025$ $(\mathrm{p}<0,05)$ yang berarti terdapat hubungan yang bermakna. Angka korelasi (r) = 0,346 yang berarti terdapat hubungan sedang yang negatif, artinya semakin tinggi emosi positif dan koping proaktif maka tekanan darah diastolik akan semakin rendah. Ditemukan pula koefisien determinasi (r) sebesar 0,121 yang berarti bahwa sekitar $12 \%$ sumbangan emosi positif dan koping proaktif terhadap variabel tekanan darah diastolik, sedangkan sisanya sebesar $88 \%$ dijelaskan oleh prediktor lain dan kesalahan kesalahan lain (eror sampling dan non sampling).

\section{Pembahasan}

Hasil analisis data menunjukkan hubungan yang signifikan antara emosi positif dan koping roaktif dengan tekanan darah sistolik dengan sumbangan sebesar $22 \%$ dan tekanan darah diastolik diastolik dengan sumbangan sebesar $12 \%$. Hal ini berarti bahwa; terdapat sekitar $22 \%$ sumbangan emosi positif dan koping proaktif terhadap variabel tekanan darah sistolik, sedangkan sisanya sebesar $78 \%$ dijelaskan oleh prediktor lain dan kesalahan kesalahan lain (eror sampling dan non sampling); dan bahwa terdapat sekitar $12 \%$ sumbangan emosi positif dan koping proaktif terhadap variabel tekanan darah diastolik, sedangkan sisanya sebesar $88 \%$ dijelaskan oleh prediktor lain dan kesalahan kesalahan lain (eror sampling dan non sampling).

Angka ini tidak begitu besar karena mengkaji emosi secara tertulis tidaklah mudah. Menurut Lucas, Diener \& Larsen (2003), seseorang seringkali menutupi apa yang sebenarnya mereka rasakan. Mereka cenderung memberi penilaian yang positif terhadap pertanyaan yang terkait dengan emosi. Heider (1991) juga menyebutkan bahwa orang minang lebih suka memendam perasaan dan kurang suka mengungkapkannya kepada orang lain. 
Kalaupun mereka ingin mengungkapkan apa yang mereka rasakan, maka mereka lebih suka mengungkapkannya dalam dendang (nyanyian). Heider (1991) merupakan salah seorang yang melakukan penelitian tentang emosi yang dibentuk oleh budaya Minangkabau, Indonesia dan Jawa serta membahas perbandingan antara peta kognitif dan emosi yang terbentuk.

Hasil analisis korelasi emosi positif dan koping proaktif sebagai variabel kontrol dengan tekanan darah sistolik, diperoleh uji signifikansi koefisien sebesar $\mathrm{p}=0,002(\mathrm{p}<0,05)$ yang berarti terdapat hubungan yang bermakna. Angka korelasi $(r)=-0,467$ yang berarti terdapat hubungan sedang yang negatif, yakni semakin tinggi emosi positif dan koping proaktif maka tekanan darah sistolik akan semakin rendah. Hasil analisis juga menunjukkan bahwa terdapat hubungan yang bermakna antara emosi positif dan koping proaktif sebagai variabel kontrol dengan tekanan darah diastolik, dimana diperoleh uji signifikansi koefisien sebesar $\mathrm{p}=0,025(\mathrm{p}<0,05)$. Angka korelasi $(\mathrm{r})=-$ 0,346 yang berarti terdapat hubungan sedang yang negatif, artinya semakin tinggi emosi positif dan koping proaktif maka tekanan darah diastolik akan semakin rendah.

Emosi positif, seperti kebahagiaan dan kepuasan, secara fisik menguntungkan karena dapat menurunkan atau menormalkan tingkat rangsang tinggi (high arousal) yang disebabkan oleh emosi negatif (Wade \& Tavris, 2007). Sebuah studi dilakukan dengan meminta peserta penelitian untuk mempersiapkan sebuah pidato dalam waktu tertentu dan mereka percaya bahwa mereka akan direkam dan akan dievaluasi oleh teman-teman sekelompok. Tugas ini secara individual menimbulkan kecemasan, vasokonstriksi perifer dan peningkatan tekanan darah sistol dan diastol. Peserta kemudian dibagi dalam 4 kelompok dan masing-masing kelompok diperlihatkan film tentang tema kegembiraan, kepuasan, netral dan kesedihan. Dugaan sementara bahwa kelompok yang melihat film dengan tema emosi positif (kegembiraan dan kepuasan) akan mengalami pemulihan kardiovaskuler tercepat. Hasilnya menunjukkan bahwa peserta dalam 2 kelompok emosi positif menunjukkan pemulihan kardiovaskuler lebih cepat dibanding peserta dari kelompok netral dan kelompok emosi negatif (kesedihan), sedangkan peserta pada kelompok emosi negatif menunjukkan menunjukkan pemulihan yang paling lama (Fredrickson \& Tugade, 2001). Temuan ini menunjukkan bahwa emosi positif memiliki kemampuan yang unik untuk menurunkan reaksi fisiologis akibat keterbangkitan emosi negatif.

Menurut Moskowitz \& Folkman (2000), bahwa seseorang dapat mengalami emosi positif, bahkan disaat situasi yang penuh stres. Hasil penelitian semakin menunjukkan bahwa emosi positif dapat memiliki pengaruh yang unik pada kesehatan, bebas dari pengaruh negatif. Emosi positif berkaitan dengan morbiditas dan mortalitas, menurunkan tekanan darah dan respon imun yang lebih baik. Emosi positif juga membantu individu memperhatikan dan memahami informasi yang lebih baik dan relevan terkait dengan kesehatannya. Informasi akan menfasilitasi pengambilan keputusan sebagai langkah penting dalam proses penyembuhan. Richman dkk (2005), melakukan penelitian untuk menguji hubungan emosi positif dengan kesehatan pada 1.041 pasien dengan 3 kategori penyakit, astma, diabetes melitus dan hipertensi. Hasilnya menunjukkan bahwa emosi positif dapat melindungi pasien dari perkembangan penyakit yang lebih buruk, dimana pasien yang mempunyai emosi positif yang tinggi mengalami kekambuhan lebih sedikit dibanding pasien dengan emosi positif yang rendah. Penelitian ini juga menguji dua emosi negatif, yaitu marah dan kecemasan. Hasilnya menunjukkan bahwa kehadiran emosi negatif tidak mempengaruhi fungsi emosi positif.

Menurut Fredickson (2000), emosi positif akan sangat membantu mengatasi 
stress dalam beberapa hal. Pertama, bahwa emosi positif akan membantu seseorang menghadapi permasalahan karena emosi positif membantu seseorang agar lebih berpikir objektif. Kedua, emosi positif dan dukungan sosial sangat berhubungan, dimana dukungan sosial akan sangat membantu meningkatkan keadaan kestabilan emosi seseorang. Sebuah studi dilakukan untuk menguji penggunaan koping proaktif pada orangtua dan hubungannya dengan depresi dan ketidakmampuan fungsional mereka. Hasilnya menunjukkan bahwa terdapat hubungan negatif antara koping proaktif dengan ketidakmampuan fungsional dan depresi (Greenglass, Fiksenbaum, Eaton, 2006). Ketiga, emosi positif akan meningkatkan kemampuan dalam menangani dampak fisik karena stress. Sebuah penelitian dilakukan dengan menginjeksikan virus flu kepada individu yang menjadi subyek penelitian. Virus flu berkembang sangat cepat pada individu dengan tingkat stres tinggi dibanding individu dengan tingkat stres rendah (Kemeny, 2008).

Emosi merupakan bagian integral dari proses koping. Penggunaan koping difokuskan pada bagaimana caranya agar saat mengalami stress, yang muncul adalah emosi positif. Stress yang dikelola dengan baik maka akan menghasilkan resolusi permasalahan yang baik, sehingga emosi positif akan mendominasi. Hal ini menunjukkan bahwa koping berasosiasi dengan emosi positif. Uji korelasi membuktikan bahwa angka korelasi lebih tinggi $(r=-0,542)$, untuk hubungan emosi positif dan tekanan darah sistolik tanpa menyertakan koping proaktif sebagai variabel kontrol. Uji korelasi menunjukkan penurunan ketika variabel koping proaktif disertakan sebagai variabel kontrol $(\mathrm{r}=$ 0,467). Hal ini dikarenakan sebagian besar responden $(76,6 \%)$ memiliki koping proaktif yang rendah.

Koping proaktif merupakan salah satu koping positif yang digunakan tidak hanya ketika stress terjadi tetapi juga ketika stres belum terjadi. Koping proaktif tidak hanya menggunakan sumber daya yang ada untuk melawan stres tetapi juga menciptakan sumber daya yang baru untuk digunakan pada stres berikutnya, apabila ada. Elemen dari koping proaktif meliputi efikasi diri, optimisme dan dukungan sosial (Greenglass, 2002). Menurut Chompton (2005), dukungan sosial dapat berdampak pada kesehatan sedikitnya dengan dua cara. Pertama, dukungan sosial dengan level tinggi dapat berpengaruh pada kesehatan secara langsung, atau dapat menjadi 'buffer' selama masa stres yang dapat mengurangi dampak negatif dari stres. Kedua, dukungan sosial dapat meningkatkan emosi positif seperti harapan, kepercayaan diri, ataupun perasaan aman.

Hal penting yang memerlukan pembahasan lebih lanjut adalah sebagian besar responden $(74,4 \%)$ memiliki emosi positif yang tinggi dan sebagian besar responden $(79,1 \%)$ juga memiliki koping proaktif yang tinggi namun tekanan darah tetap tidak terkontrol. Data distribusi frekuensi tekanan darah yang ditunjukkan pada Tabel 4 (hal20), menunjukkan bahwa $58,1 \%$ responden memiliki tekanan darah sistolik diatas $140 \mathrm{mmHg}$ dan 34,9\% responden memiliki tekanan darah diastolik diastolik diatas $90 \mathrm{mmHg}$. Menurut penanggung jawab Poli Khusus Jantung/Hipertensi, masih banyaknya pasien yang tidak dapat mengontrol tekanan darah pada batas normal (dibawah 140/90 mmHg) cenderung disebabkan karena pasien tidak patuh terhadap pengobatan farmakologi dan nonfarmakologi. Misalnya saja, masih banyak pasien yang datang ke poli setelah obat habis. Seharusnya pasien datang ke poli sebelum obat habis sehingga tidak terjadi putus obat yang dapat mengakibatkan naiknya tekanan darah. Pasien juga cenderung tidak mengikuti diet hipertensi sesuai instruksi dokter sehingga dapat berdampak terhadap kenaikan tekanan darah. 
Tingkat kepatuhan yang tinggi terhadap pengobatan hipertensi akan meningkatkan efektifitas pengobatan dan mencegah episode yang lebih buruk dari penyakit hipertensi, serta dalam jangka panjang akan menurunkan tekanan darah sehingga dapat menurunkan morbiditas dan mortalitas pasien hipertensi. Ketika tekanan darah kurang dari $140 / 90 \mathrm{mmHg}$ selama satu tahun, maka penurunan dosis dan tipe obat antihipertensi dapat dianjurkan (Indonesia Kidney Care Club, 2009), bahkan pola hidup sehat dapat mengelola hipertensi tanpa obat (Vitahealth, 2004).

\section{KESIMPULAN DAN SARAN Kesimpulan}

Berdasarkan hasil analisis yang telah diuraikan, maka dapat ditarik beberapa kesimpulan:

1. Sebagian besar responden $(74,4 \%)$ memiliki emosi positif dengan kategori tinggi.

2. Sebagian besar responden $(79,1 \%)$ memiliki koping proaktif dengan kategori tinggi.

3. Lebih dari sebagian responden $(58,1 \%)$ memiliki tekanan darah diastolik yang tidak normal (diatas $140 \mathrm{mmHg}$ ).

4. Lebih dari sebagian responden $(65,1 \%)$ memiliki takanan darah diastolik yang normal (dibawah 90 $\mathrm{mmHg}$ )

5. Terdapat hubungan yang bermakna antara emosi positif dan koping proaktif sebagai variabel kontrol dengan tekanan darah sistolik, dimana diperoleh uji signifikansi koefisien sebesar $\mathrm{p}=0,002(\mathrm{p}<0,05)$.

6. Terdapat hubungan sedang yang negatif antara emosi positif dan koping proaktif sebagai variabel kontrol dengan tekanan darah sistolik, dimana angka korelasi $(r)=-0,467$ yang artinya semakin tinggi emosi positif dan koping proaktif maka tekanan darah sistolik akan semakin rendah.
7. Sekitar $22 \%(r=0,218)$ sumbangan emosi positif dan koping proaktif terhadap variabel tekanan darah sistolik, sedangkan sisanya sebesar $78 \%$ dijelaskan oleh prediktor lain dan kesalahan kesalahan lain (eror sampling dan non sampling).

8. Terdapat hubungan yang bermakna antara emosi positif dan koping proaktif sebagai variabel kontrol dengan tekanan darah diastolik, dimana diperoleh uji signifikansi koefisien sebesar $\mathrm{p}=0,025(\mathrm{p}<0,05)$.

9. Terdapat hubungan sedang yang negatif antara emosi positif dan koping proaktif sebagai variabel kontrol dengan tekanan darah diastolik, dimana angka korelasi $(r)=$ $-0,467$ yang artinya semakin tinggi emosi positif dan koping proaktif maka tekanan darah diastolik akan semakin rendah.

10. Terdapat sekitar $12 \%(\mathrm{r}=0,121)$ sumbangan emosi positif dan koping proaktif terhadap variabel tekanan darah diastolik, sedangkan sisanya sebesar $78 \%$ dijelaskan oleh prediktor lain dan kesalahan kesalahan lain (eror sampling dan non sampling).

\section{Saran}

1. Diharapkan kepada RS. Dr. M. Djamil padang untuk dapat memberikan pelatihan tentang manajemen emosi dan koping proaktif sehingga pasien memiliki pengetahuan dan keterampilan dalam mengelola stres yang pada akhirnya dapat menurunkan tekanan darah pada rentang normal.

2. Diharapkan kepada Institusi Pendidikan agar dapat menciptakan modul sederhana terkait dengan manajemen emosi dan koping proaktif sehingga dapat menjadi panduan bagi pasien.

3. Diharapkan kepada pasien hipertensi untuk mengikuti pelatihan terkait dengan emosi dan koping apabila diadakan. 
4. Menindaklanjuti penelitian ini dengan menambahkan variabel lain seperti tingkat kepatuhan, diet hipertensi dan olah raga.

\section{DAFTAR PUSTAKA}

Adriantoro, H. (2008). Hipertensi, Ancam Kelaki-lakian Anda. Diakses dari www.f-buzz.com. Pada tanggal 1 Februari 2010.

Azwar, S. (2007). Penyusunan Skala Psikologi. Yogyakarta. Pustaka Belajar.

Compton,W.C. (2005). Introduction to Positive Psychology. USA. Thomson Wadsworth.

Craty, R.M., Atkinson, M \& Tomasino, D. (2003). Impact of a workplace stress reductions program on blood pressure and emotional health in hypertension employees. Journal of Alternative and Complementary Medicine, 9, (3), 355-369.

Clarak, M.S. (1992). Emotion. Review of Personality and Social Psychology. USA. Sage Publication, Inc

Departemen Kesehatan RI. (2007). Hipertensi Penyebab Utama Penyakit Jantung.. Diakses dari www.depkes.go.id pada tanggal 30 Nopember 2009.

Davidson, G.C., Neale, J.M. \& Ann, M.K. (2004). Psikologi Abnormal. (Terjemahan). Jakarta. Raja Grafindo Persada.

Fatimah, A. (2007). Pengaruh Logoterapi terhadap Hipertensi pada Pasien Lanjut Usia. Diakses dari www.digilib.uns.ac.id pada tanggal 25 januari 2010.

Fredrickson, B.L. (2000). Cultivating Positive Emotion to Optimize Health and Well-Being. American Psychological Association Prevention \& Treatment 3 Article 0001a.
Ganong, W.F. (2001). Buku Ajar Fisiologi Kedokteran. (Terjemahan). Jakarta. EGC

Goleman, D. (1995). Kecerdasan Emosional. (Terjemahan) Jakarta. Gramedia Pustaka Utama

Greenglass, E., Fiksenbaum, L., Eaton, J. (2006). The Relationship Between Coping, Social Support, Functional Disability and Depression in The Eldery. Anxiety, Stress, and Coping. 19(1):15-31.

Hardy, M., Heyes, S. (1985). Pengantar Psikologi. (terjemahan). Yogyakarta. Erlangga.

Hapsari, K.S.T.P. (2004). Hubungan Dukungan Sosial dan Strategi Koping dengan Rasa Nyeri pada Penderita Osteoartritis. Tesis (Tidak diterbitkan). Yogyakarta. Fakultas Psikologi Universitas Gajah Mada.

Hartono. (2008). SPSS 16.0 Analisis Data Statistika dan Penelitian. Yogyakarta. Pustaka Pelajar.

Horne, M..M. (1993). Keseimbangan Cairan Elektolit dan Asam Basa. (Terjemahan). Jakarta. EGC.

Indonesion Society of Hypertension. (2007). JNHC: Hipertensi Terkontrol, Selamatkan Ginjal. Diakses dari www.majalahfarmacia.com pada tanggal 1 Februari 2010.

Ikatan Dokter Indonesia. (2009). Manajemen Hipertensi. Diakses dari www.idijakbar.com. Pada tanggal 30 Nopember 2009.

Kaplan, G.A., Goldberg, D.E., \& Salone, J.T. (2000). Hypertension incidence is predcted by high levels of hopleesness in finish men. American Heart Association inc, 35, 561-567.

Kemeny, M.E. (2008). Stress and Immune System the Truth About PsychoNeuroImmunology. Diakses dari www.youtube.com pada tanggal 1 januari 2010.

Lazarus, R.S. ( 1991). Emotion \& Adaptation. New York. Oxford University Press,Inc 
Lazarus, Folkman, S. (1984). Stess, Apraisal and Coping. New York. Springer Publishing.Company. Inc

Lucas, R.E., Diener, E., Larsen, R.J. (2009). Measuring Positive Emotion. In Lucas, R.E., Diener, E. (ed). Social Indikators Research Series Assessing Well Being. USA. Springer. diakses dari www.google.book.com pada tanggal 25 Januari 2010.

Larsen, R.J. (2009). Affect Intensity. In Leary, M.R., Hoyle, R.H. (ed). Handbook of Individual Differences In Social Behavior. New York. Guilford Publication, Inc. diakses dari www.google.book.com pada tanggal 25 Januari 2010.

Lany, G. (2001). Hipertensi. Tekanan Darah Tinggi. Yogyakarta. Kanisius

Moskowitz, J. (2009). Positive Emotion in the Midst of Stres: It's not Crazy, It's Adaptive. Diakses dari www.youtobe.com pada tanggal 28 Januari 2010.

Muslich, M. (2007). Makna Emosi dan Norma Budaya dalam Bahasa Indonesia. Diakses dari www.muslich-m.blogspot.com pada tanggal 10 Agustus 2009

Mike, R. (2007). Mukjizat Bersyukur dan Bermental Positif. (Terjemahan). San Fransisco. Jassey-Bas.

Markovitz, ect. (1993). Psycholoical Predictor of Hypertension in The Framingham Study: Is There Tension in Hypertension?. Chicago. JAMA 270(20), 2439

Mulyaningsih, D.K (2001). Tesis (Tidak diterbitkan). Peran Pelepasan Emosi pada Pasien Pasca Stroke dengan Faktor Risiko Hipertensi. Yogyakarta. Fakultas Psikologi Universitas Gajah Mada.

Ostir, G.V., Berges, E.M., Markides, K.S \& Ottenbackher, K.J. (2006). Hypertension in older adulth and role of positive Emotions. Psychosomatic Medicine Baltimone, 68, (5), 727-733.
Praptianingsih, S. (2007). Kedudukan Hukum Perawat dalam Pelayanan Kesehatan di Rumah Sakit. Jakarta. PT GrafindoPersada.

Potter, D.A \& Derry, A.G. (1997). Fundamentals of Nursing: Concepts, Proces and Pratice. Mosing Years Book inc.

Perini, C., Smith, D., Nented, J., Smith, M \& Hendy, J.P.B. (1994). A repressive coping style proactive from emotional distress in low renin essential hypertensive. Journal of Hypertension, 12, (5), 601-608.

Pinzon, R. (2009). Ancaman "the Silent Killer". Diakses dari www.artikelindonesia.com pada tanggal 1 Februari 2010.

Richman, L.S., Lauro, K., Maselko, J., Kawachi, I., Choo, P., Bauer, M. (2005) Positive Emotion and Health: going Beyond The Negative. Health Psychology 24(4), 422-429.

Rogers, W. (1995). Anatomi dan Fisiologi untuk Perawat. (Terjemahan). Jakarta. EGC

Rotella, M. (1998). Hearling hypertension: uncorering the secret power of your hidden emotion. Publisher Weekly. New York, 7, (254), 49-56.

Santrock, J.W. (2002). Life-Span Development. (Terjemahan). Boston. McGraw-Hill

Santrock, J.W. (2006). Human Adjustment. Boston. McGraw- Hill.

Shane, J. \& Snyder, C.R. (2003). Positive Psychology Assesment: a Hanbook of Models and Measure. American Psychology Association.

Syaifuddin. (2006). Anatomi dan Fisiologi untuk Perawat. Jakarta. EGC

Soejoeti, S.Z. (2005). Konsep Sehat, Sakit \& Penyakit dalam Konteks Sosial Budaya. Diakses dari www.kalbe.co.id pada tanggal 30 Nopember 2009

Taylor, S.E. (1995). Healt Psychology. Singapore. McGraw-Hil Book. *

Tugade, M.M. , Fredrickson, B.L., Barrett, L.F. (2004). Psyichological 
Resilience and Positive Emotional Granularity: Examining the Benefits of Positive Emotion on Coping and Health. Blackwell Publishing. Journal of Personality 72(6)

Departemen Kesehatan Indonesia. Undang-Undang Kesehatan Nomor 23 tahun 1992. Diakses dari www.depkes.go.id pada tanggal 30 Nopember 2009.

Vogele., Stephou, C. \& Andrew. (1992). Emotional coping and tonic blood pressure as determinants of cordiovascular responses to mental stress. Journal of Hypertension, 10, (9), 1079-1088.

Wade, C \& Tavris, C. (2007). Psikologi. (Terjemahan). Pearson Education, Inc.
World Health Organization. (2003). World Health Organization (WHO)/International Society of Hypertension (ISH) statement on management of hypertension. Diakses dari www.who.int pada tanggal 25 Agustus 2009.

Wirtz, P.H., Kanel, R., Mohiyeddini, C., Emini, L., Ruedisueli, K., Groessbauer, S., Ehlert, U. (2006). Low Social Support and Poor Emotional Regulation are Associated With Increased Stress Hormone Reactivity to Mental Stress in Systemic Hypertension. Journal of Endokrin Metab. 10,1210.

Wikipedia. (2008). Health. Diakses dari www.wikipedia.org pada tanggal 10 Agustus 2009. 